Journal of Advanced College of Engineering and Management, Vol. 5, 2019

\title{
BIOLOGICAL DENITRIFICATION OF NITRATE CONTAMINATED GROUND WATERWITH ELEMENTARY SULFUR
}

\author{
Madan Gorathoki ${ }^{1}$, Iswar Man Amatya ${ }^{2}$ \\ ${ }^{1}$ M.sc. in Environmental Engineering, Pulchowk Campus, T.U. \\ ${ }^{2}$ Assoc.Prof., Department of Civil Engineering,Pulchowk Campus, T.U.
}

\begin{abstract}
Extensive utilization of synthetic fertilizer and release of improperly treated wastewater from industrial or municipal facilities are the causes of nitrate contamination in natural water systems. Nitrate is one of the main contributors to eutrophication of surface water bodies which can cause severe ecological and environmental problems. Consumption of nitrates can have several detrimental health effects. One adverse health effect is methemoglobinemia or "blue-baby" syndrome.

Sulfur based biological denitrification process is autotrophic denitrification using Thiobacillus denitriflcans, in which process is conducted by denitrifying bacteria which require inorganic carbon for carbon source. These denitrifying bacteria oxidizes elemental sulfur to sulphate while reducing nitrate to nitrogen gas, thereby eliminating the need for addition of organic carbon compounds as energy sources to drive denitrification.

This Study was conducted on biological denitrification with elemental sulfur packed small-scale bed columns and it was found to be maximum 39 percent efficiency of $\mathrm{NO}_{3}-\mathrm{N}$ removal at 1.5 hours HRT having bicarbonate range 153.72 to 207.40 $\mathrm{mg} / \mathrm{l}$ and that of TIN removal was up to 35 percent removal efficiency. In this biological process, elemental sulfur is converted into sulfate, and this renders the method unsuitable for the treatment of ground water containing high levels of endogenous sulfate.
\end{abstract}

Keywords: Denitrification; Elemental sulfur; Thiobacillus denitrificans, nitrate reduction

\section{Background}

Nitrate contamination of groundwater is a global issue that has stimulated significant research interest. Biological denitrification refers to the dissimilatory reduction, by essentially denitrifying bacteria of one or both of the ionic nitrogen oxides (nitrate, and nitrite) to the gaseous oxides (nitric oxide and nitrous oxide), which may themselves be further reduced to nitrogen. Elemental sulfur is an insoluble (Sierra-Alvarezet al, 2007) and source of energy for biological denitrification of nitrate contaminated groundwater (Soares, 2002). A few species of sulfur utilizing autotrophic denitrifiers, such as Thiobacillus denitrificans (Moon--Bandpiet al., 2008) and Thiomicrospira denitrificans (Brettar et al., 2006), have been found to reduce nitrate to nitrogen gas and most commonly detected sulfur oxidizing denitrifying bacteria (SOB) is Thiobacillusdenitrificans (Cardoso et al, 2006). The following is a stoichiometric equation, which shows an example of elemental-sulfur-utilizing autotrophic denitrification (Koenig and Liu, 2001).

$$
1.06 \mathrm{NO}_{3}{ }^{-}+1.11 \mathrm{~S}+0.3 \mathrm{CO}_{2}+0.785 \mathrm{H}_{2} \mathrm{O} \longrightarrow 0.5 \mathrm{~N}_{2}+1.11 \mathrm{SO}_{4}{ }^{2-}+1.16 \mathrm{H}^{+}+0.06 \mathrm{C}_{5} \mathrm{H}_{7} \mathrm{O}_{2} \mathrm{~N}
$$

The nitrogen oxides act as terminal electron acceptors (Rossi et al, 2015) and sulfur compounds like sulfide, elemental sulfur, thiosulfate or sulfite as electron donorswhile inorganic carbon compounds like bicarbonate as a carbon source to convert nitrate to nitrite, and subsequently to nitrogen gas (Cardoso et al, 2006;Mohseni et al., 2013; EPA, 2002). In the process, elemental sulfur is converted into sulfate, and this renders the method unsuitable for the treatment of drinking water containing high levels of endogenous sulfate (Soares, 2002). 
Nitrate nitrogen profiles of autotrophic denitrification in sulfur packed-bed reactors can be evaluated according to the half-order reaction model using the equation (Koenig and Liu, 2001) $\mathrm{C}_{\mathrm{e}} 1 / 2=\mathrm{C}_{\mathrm{in}}{ }^{1 / 2}-$ $1 / 2 \mathrm{~K}_{(1 / 2)} \mathrm{t}$ : where $\mathrm{C}_{\mathrm{e}}{ }^{1 / 2}$ is effluent concentration, $\mathrm{C}_{\text {in }}{ }^{1 / 2}$, half-order reaction rate constant per unit reactor volume and ' $t$ ' is hydraulic retention time.

This study was done to investigate denitrification of nitrified ground water using autotrophic metabolism with $\mathrm{S}_{0}$ as electron donor up-flow mode sulfur packed bed reactors at in situ condition of inorganic carbon sources to drive denitrification process and also to model the relationship between half order reaction rate constant and hydraulic retention time.

\section{Methodology}

\section{Experimental apparatus}

The experimental program on autotrophic denitrification using elemental sulfur was carried out in a continuous up-flow reactor. The denitrification reactor was a glass column packed with sulfur particles which is pre-washed to remove any powdered sulfur. The schematic diagram of flow reactor is as shown in figure below.

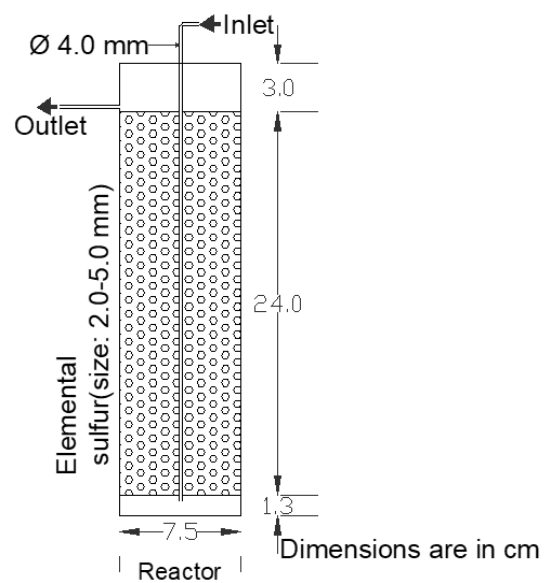

Figure 1: Schematic Representation of the Experimental Apparatus

Table 1: Characteristics of denitrification reactor

\begin{tabular}{|c|c|}
\hline Components & Dimension/weight \\
\hline Height & $24 \mathrm{~cm}$ \\
\hline Diameter & $7.5 \mathrm{~cm}$ \\
\hline Particle size & $2.0-5.0 \mathrm{~mm}$ \\
\hline Sulfur dry weight & $1367.4 \mathrm{~g}$ \\
\hline
\end{tabular}

Enrichment of Thiobacillus denitrificans and inoculation of reactors

Cultures of Thiobacillus denitrificans were prepared from sludge obtained from an oxidation sediment from Guheshwori Wastewater Treatment plant Bagmati and incubated in an anaerobic chamber in the medium described by Claus and Kutzner (1985).

\section{Sampling and Analytical methods}

Samples were collected for analysis when steady-state conditions had been attained. Samples were collected from the influent and effluent of the reactor. 
Table 2: Examination parameters, instruments and methods

\begin{tabular}{|c|c|c|}
\hline $\mathrm{SN}$ & Parameters & Methods/ Instruments \\
\hline 1 & $\mathrm{NH}_{4}-\mathrm{N}, \mathrm{NO}_{3}-\mathrm{N}$ and $\mathrm{NO}_{2}-\mathrm{N}$ & Spectrophotometer \\
\hline 2 & $\mathrm{pH}$ & Standard $\mathrm{pH}$ meter; Lutron $\mathrm{pH}$-223 (Range: 0-14) \\
\hline 3 & $\mathrm{HCO}_{3}^{-}$ & Volumetric Analysis by Titration method \\
\hline 4 & $\mathrm{TOC}$ & TOC - UVA, TOC analyzer \\
\hline 5 & Temperature & Thermometer \\
\hline 6 & Sulfate & Gravimetric method \\
\hline
\end{tabular}

\section{Result and Conclusion}

The reactor was operated for 97 days with influent feed solution taken from dripping nitrification system which is located near Girls hostel of IOE Pulchowk Campus. Study was conducted on 5 different hydraulic retention time (HRT) i.e. 0.85, 1.2. 1.5, 2.85 and $4.42 \mathrm{hrs}$. The column was kept in the dark, at the temperature of $24 \pm 2^{\circ} \mathrm{C}$ and bicarbonate concentration was measured on range 153.72 to $207.40 \mathrm{mg} / \mathrm{l}$ during study period on inlet sample.

The highest removal of efficiency of nitrate was obtained at HRT $1.5 \mathrm{hrs}$. with 39 percent and that of Total Inorganic Nitrogen(TIN) removalwas 35 percent. Nitrite is the intermediate form during denitrification in which it is further reduced to nitrogen gas by denitrifying bacteria (EPA, 2002). During study nitrite concentration was increased in all outlet samples on all HRT and it was formed maximum concentration on HTR 2.85 up to $9.36 \mathrm{mg} / \mathrm{l}$.

During study the $\mathrm{pH}$ was slightly decreased because of inorganiccarbon used in the process.Also, there was formation of sulfate up to $181 \mathrm{mg} / 1$ in the effluent(Figure:7). Theconcentrations of TOC in eachsample's effluent were less than $3 \mathrm{mg} / \mathrm{l}$ and change in ammonia concentration on effluent was found to be insignificant

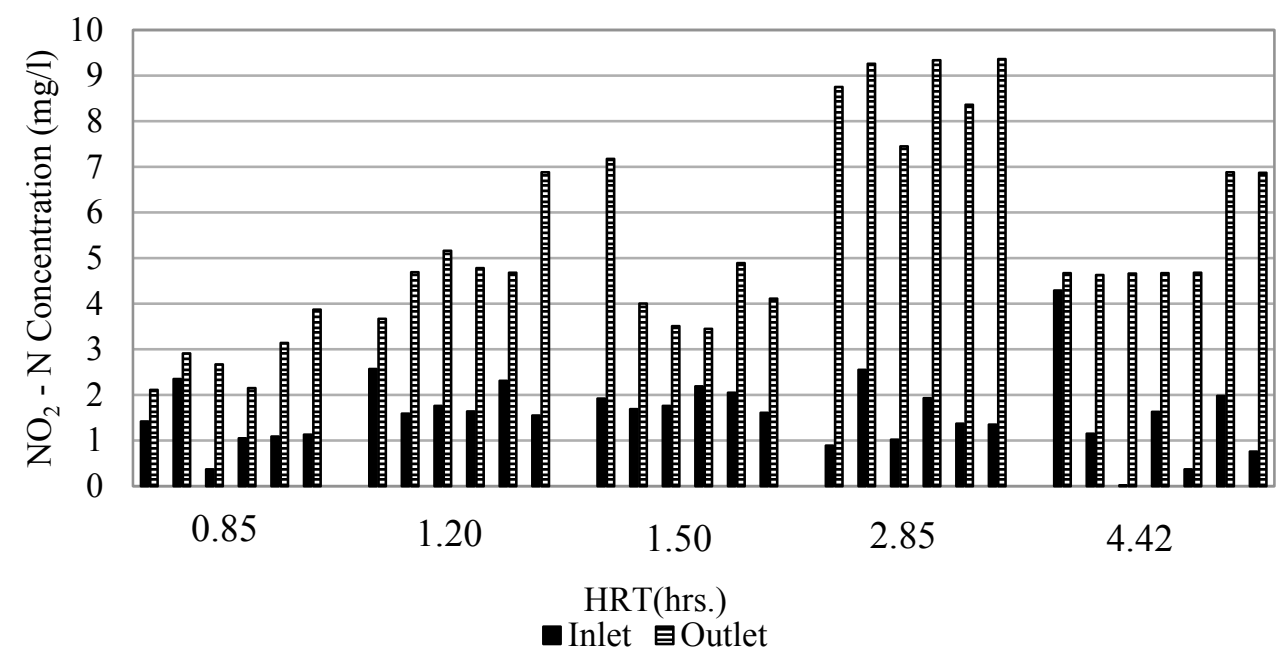

Figure 2: $\mathrm{NO}_{2}-\mathrm{N}$ Concentrations 


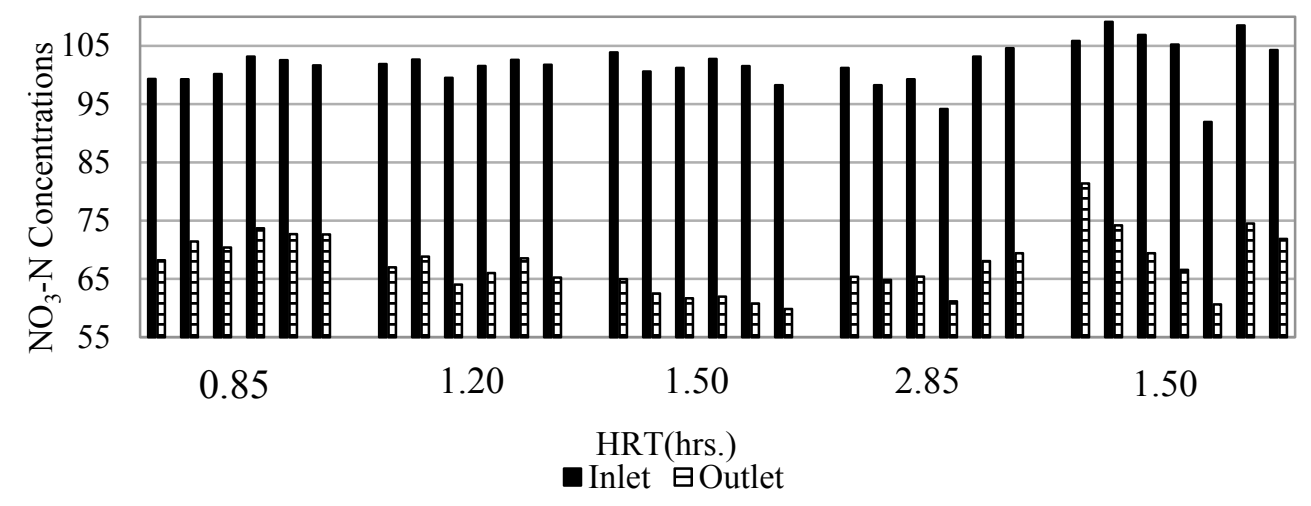

Figure 3: $\mathrm{NO}_{3}-\mathrm{N}$ concentrations

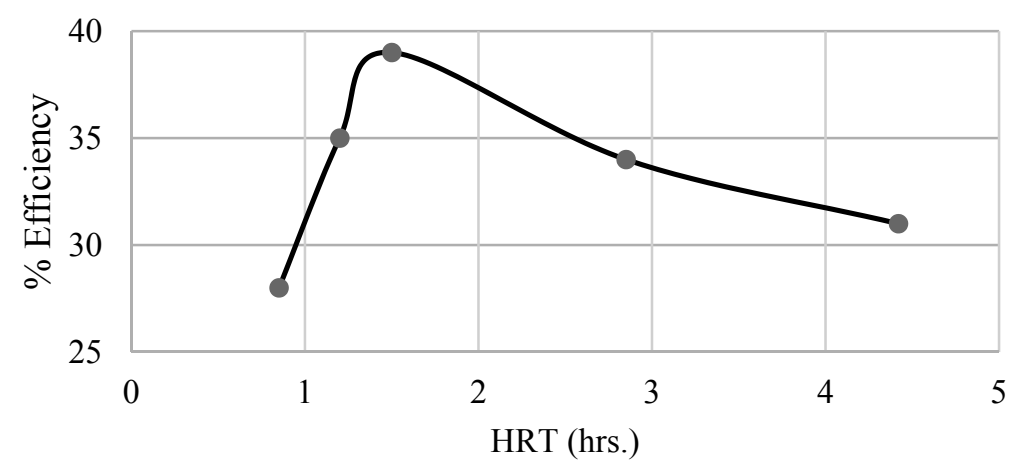

Figure 4: Removal Efficiency vs $\mathrm{HRT}$ for $\mathrm{NO}_{3}-\mathrm{N}$ concentration

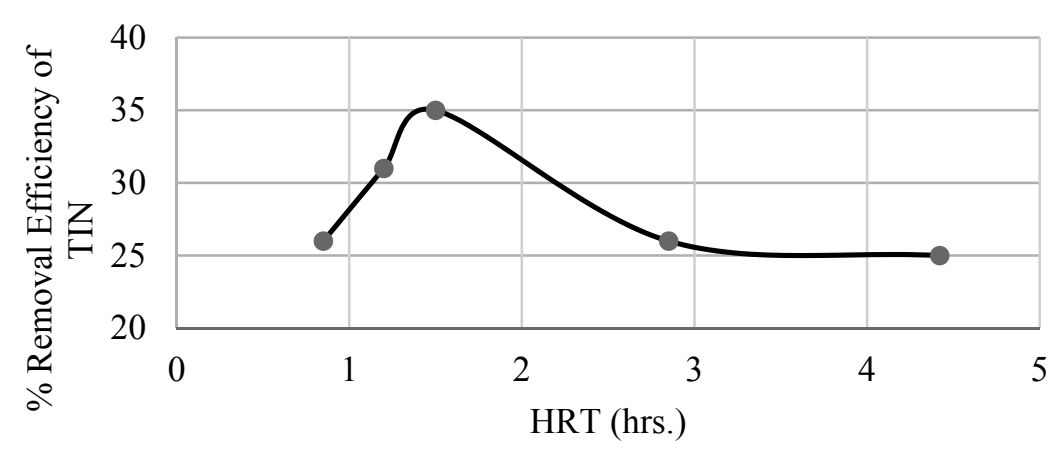

Figure 5: Removal Efficiency vs HRT for TIN concentration 


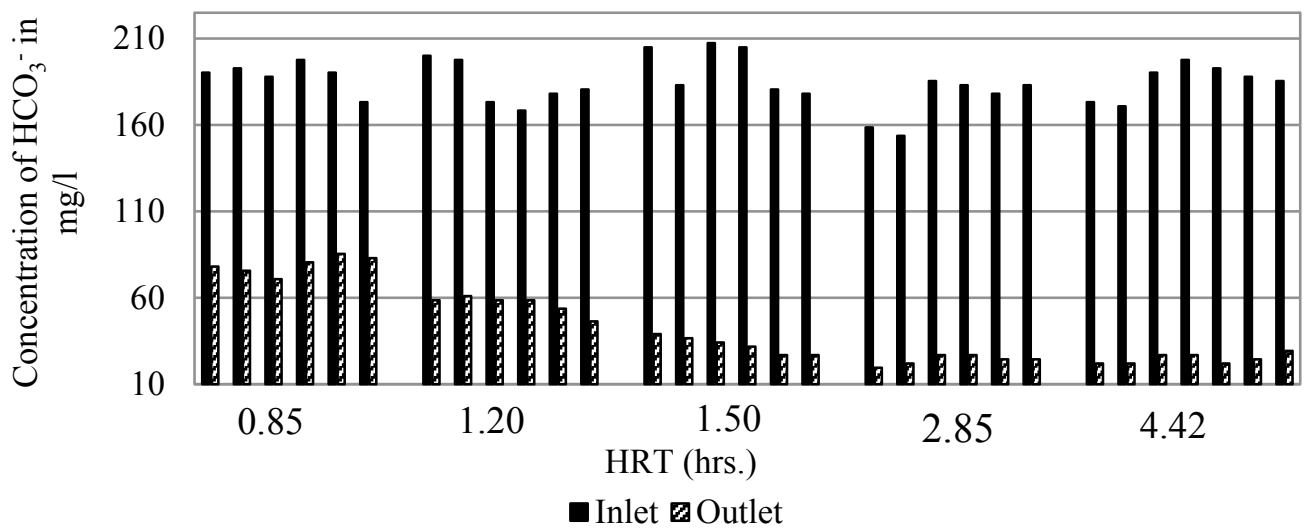

Figure 6: $\mathrm{HCO}_{3}{ }^{-}$concentration

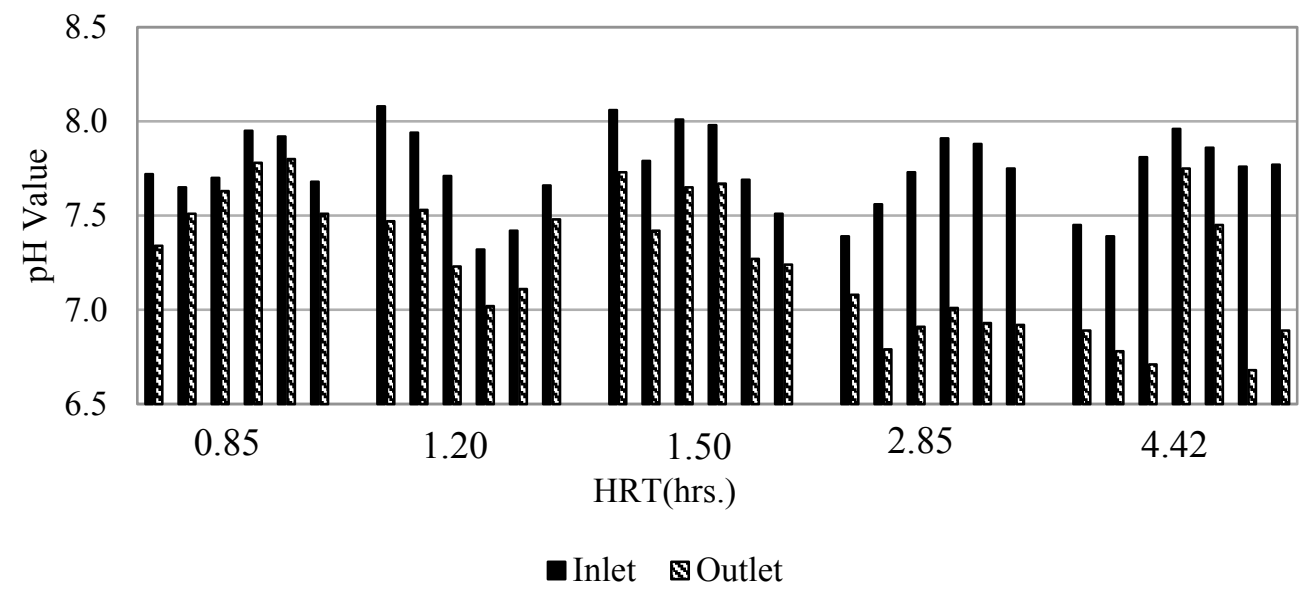

Figure 6: $\mathrm{pH}$ value

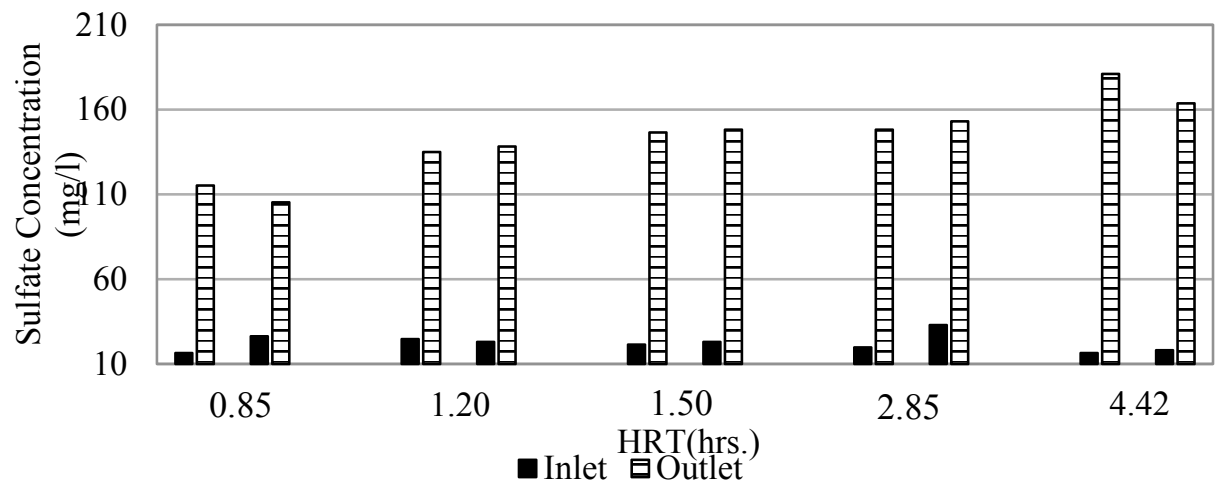

Figure: 7: Sulfate concentration

\section{Mathematical Model for Nitrate Reduction}

As Bacterial activities for reduction of Nitrogen compounds depends on how much time the water sample gets retains on reactor, by Koenig and Liu (2001) removal of nitrate compound in column packed reactor is reduced by half-order kinetics in sulfur-based denitrification so from this recommendation and study for nitrate contaminated ground water done and following result was obtained the relation between Hydraulic retention time(HRT) and half-order reaction rate constant per unit volume as tabulated in table . 
Table 4: Calculation for half-order reaction rate constant per unit reactor volume ' $\mathrm{K}$ '

\begin{tabular}{|c|c|}
\hline HRT (hrs.) & Half-order reaction rate constant 'K' \\
\hline 0.85 & 3.643 \\
\hline 1.20 & 3.299 \\
\hline 1.50 & 2.955 \\
\hline 2.85 & 1.321 \\
\hline 4.42 & 0.746 \\
\hline
\end{tabular}

The Half-order reaction rate constant was found to be decreasing as increase in HRT for influent concentration around $100 \pm 10 \mathrm{mg} / \mathrm{l}$, and the relation between them can be found the by mathematical model as in figure 7 :

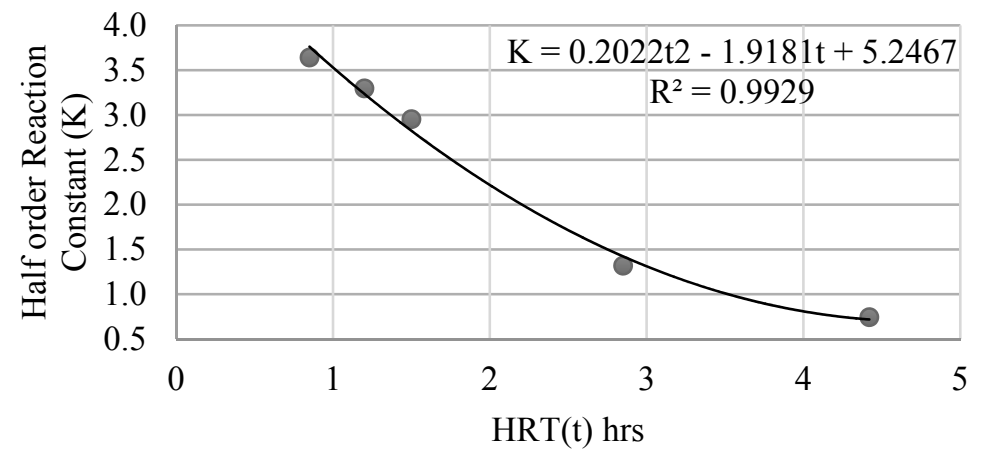

Figure 7: Curve of HRT vs Half Order Reaction Rate 'K'

\section{Conclusions}

Based on the results of literature review, and detailed experimental programs continuous up-flow sulfur-packed column, it is concluded that the biological denitrification is a viable process for nitrate removal from groundwater supply sources for low concentration of nitrate concentration, if the ground water contains low concentration of bicarbonate $(153.72-207.40 \mathrm{mg} / \mathrm{l})$. This process offers a distinct advantage over the heterotrophic denitrification as no external carbon source is necessary. Nitrate removal in the continuous flow sulfur-packed up-flow reactor was accompanied by bicarbonates destruction and sulfate generation. As nitrate is reduced, sulfur is oxidized to sulfate. Since the nitrate is reduced by formation of sulfate concentration, if ground water contains high concentration of sulfate then this method may not suitable for nitrate removal.

Also, mathematical relationship derived between HRT and half-order reaction rate constant per unit reactor volume will help for prediction of effluent concentration of nitrate for different HRT value on sulfur packed up flow column reactor.

\section{Recommendations}

It is recommended that a full-scale or pilot plant field study be initiated. This study will provide an opportunity to evaluate the effects of many key factors upon the performance of the autotrophic denitrification process. The research strategy for field investigation may include:

- The effect of temperature variation upon the nitrate removal, and nitrite build up in the ground water will be established from the seasonal temperature variation data.

- The $\mathrm{NO}_{2}-\mathrm{N}$ buildup in the effluent at high $\mathrm{NO}_{3}-\mathrm{N}$ loading is a cause of concern. It is recommended the effluent recycle through the reactor be investigated using external inorganic carbon sources. Effluent recycle will increase the $\mathrm{NO}_{2}-\mathrm{N}$ concentrations in the feed thus may accelerate the limiting reaction rate from $\mathrm{NO}_{2}-\mathrm{N}$ to $\mathrm{N}_{2}$. 
- Research may be done to determine optimum efficiency on optimum bicarbonate sources. In this study bicarbonate as inorganic carbon sources are found to be limiting case resulting lower removal efficiency of nitrate and nitrite formation on effluent concentration.

\section{References}

1. Brettar Ingrid, Labrenz Matthias, FlavierSe'bastien, Julia, BotelHarriKuosa, Christen Richard, and Hofle Manfred G. "Identification of a Thiomicrospira denitrificans-Like Epsilonproteobacterium as a Catalyst for Autotrophic Denitrification in the Central Baltic Sea". Applied and Environmental Microbiology, Feb. 2006, P. 1364-1372.

2. Claus Giinter and Kutzner Hans Jiirgen,"Autotrophic denitrification by Thiobacillus denitrificans in a packed bed reactor". Appl Microbiol Biotechnol (1985) 22:289-296.

3. Environmental Protection Agency (EPA) "Nitrification". United states, August 15, 2002.

4. Koenig A. And Liu L. H. "Kinetic Model of Autotrophic Denitrification in Sulphur PackedBed Reactors", Wat. Res. Vol. 35, No. 8, pp. 1969-1978, 2001.

5. Mohseni-BandpiAnoushiravan, Elliott David Jack and Zazouli Mohammad Ali " Biological nitrate removal processes from drinking water supply-a review" Journal of Environmental Health Sciences \& Engineering 2013, 11:35. pp 2, 6

6. Moon H.S., Ahn K.-H., Lee S., Nam K., Kim J.Y. "Use of autotrophic sulfur-oxidizers to remove nitrate from bank filtrate in a permeable reactive barrier system" Environmental Pollution 129 (2004) 499-507. pp 499.

7. Rossi Federico, Motta Oriana, Matrella Simona, Proto Antonio and Vigliotta Giovanni " Nitrate Removal from Wastewater through Biological Denitrification with OGA 24 in a Batch Reactor" Water 2015, 7, 51-62; doi:10.3390/w7010051. pp 52.

8. Sierra-Alvarez Reyes, Beristain-Cardoso Ricardo, Salazar Margarita, Go'mez Jorge, RazoFlores Elias, Field Jim A." Chemolithotrophic denitrification with elemental sulfur for groundwater treatment" Water Res. 41 (2007), pp. 1253-1262.

9. Soares, M.I.M.:2002,"Denitrification of Ground water with Elemental Sulfur", Water Research, 36(5), 1392-1395. 